\title{
Thermal and moisture flux in soft fibreboards
}

\section{Journal Article}

Author(s):

Sonderegger, Walter; Niemz, Peter

Publication date:

2012-01

Permanent link:

https://doi.org/10.3929/ethz-b-000041493

Rights / license:

In Copyright - Non-Commercial Use Permitted

Originally published in:

European Journal of Wood and Wood Products 70(1-3), https://doi.org/10.1007/s00107-010-0498-7 


\title{
Thermal and moisture flux in soft fibreboards
}

\author{
Walter Sonderegger $\cdot$ Peter Niemz
}

Received: 11 November 2009 / Published online: 18 November 2010

(C) Springer-Verlag 2010

\begin{abstract}
The thermal conductivity of several wet and dry processed industrial soft fibreboards was determined at temperatures between $10^{\circ} \mathrm{C}$ and $30^{\circ} \mathrm{C}$. Additionally, the thermal conductivity was tested relative to the moisture content ranging from an oven-dry sample to a moisture content of $85 \%$ relative humidity. Furthermore, the water vapour diffusion was investigated to determine the resistance factor and the diffusion coefficient under 'dry cup' and 'wet cup' conditions and the sorptions were tested by means of the sorption isotherms.

The thermal conductivity increases with increasing temperature at about $0.45 \%$ per Kelvin and with increasing moisture at about $0.17 \times 10^{-2} \mathrm{~W} / \mathrm{mK}$ per percent volumetric moisture content. Furthermore, the thermal conductivity depends on the manufacture (dry or wet process) and is influenced by density. The water vapour resistance factor increases and the diffusion coefficient decreases with increasing density. Both factors decrease with increasing moisture content and they are dependant on board thickness, composition and manufacturing. The sorption isotherm is similar to solid wood below about $80 \%$ relative humidity but strongly increases for soft fibreboards with binding fibres and additives of ammonium phosphate or sodium borate and boric acid when above $80 \%$ relative humidity.
\end{abstract}

\section{Wärme- und Feuchteverhalten poröser Holzfaserplatten}

Zusammenfassung An verschiedenen, nach dem Nassoder nach dem Trockenverfahren, industriell hergestellten

W. Sonderegger $(\varangle) \cdot$ P. Niemz

Institute for Building Materials, Wood Physics, ETH Zurich,

Schaffmattstrasse 6, 8093 Zurich, Switzerland

e-mail: wsonderegger@ethz.ch
Holzfaserdämmplatten wurde die Wärmeleitfähigkeit in Abhängigkeit von der Temperatur zwischen $10^{\circ} \mathrm{C}$ und $30^{\circ} \mathrm{C}$ geprüft. An einem Teil der Platten wurde die Wärmeleitfähigkeit zusätzlich in Abhängigkeit von der Feuchte, von darrtrocken bis zu einer Feuchte bei $85 \%$ relativer Luftfeuchte, bestimmt. Weiterhin wurden die Wasserdampfdiffusion unter Ermittlung der Diffusionswiderstandszahlen und der Diffusionskoeffizienten im Trocken- und im Feuchtbereich sowie das Sorptionsverhalten anhand der Sorptionsisothermen untersucht.

Die Wärmeleitfähigkeit steigt mit zunehmender Temperatur um $0,45 \%$ pro Kelvin und mit zunehmender Feuchte um $0,17 \times 10^{-2} \mathrm{~W} / \mathrm{mK}$ pro Prozent volumenbezogenen Feuchtegehalts. Zusätzlich besteht eine Abhängigkeit von der Dichte sowie vom Herstellungsverfahren (Nassoder Trockenverfahren). Während mit zunehmender Dichte die Wasserdampfdiffusionswiderstandszahl steigt, verringert sich der Diffusionskoeffizient. Beide Kenngrößen nehmen mit zunehmender Feuchte $a b$ und sind abhängig von der Probendicke, der Zusammensetzung und dem Herstellungsverfahren. Bis ca. $80 \%$ relativer Luftfeuchte verhält sich die Sorptionsisotherme ähnlich wie diejenige von Vollholz, oberhalb davon steigt sie jedoch bei den Holzfaserdämmplatten mit Bindefasern sowie Zusätzen von Ammoniumphosphat oder Borsäure und Borax steil an.

\section{Introduction}

Soft fibreboards constructed of wood fibres are used as insulating materials with specialized heat insulation and storage properties that induce a high phase lag from the external wall temperature to the interior room. Therefore, they are suitable for winter and summer heat insulation and have 
become more important in recent years. Certain characteristics of the materials, such as the thermal conductivity, water vapour diffusion and water sorption, are important for structural-physical calculations.

General mean values of thermal conductivity and water vapour resistance of insulating materials are available from industrial data sheets partially listed in reference books (e.g. Reyer et al. 2002). Thereby, the water vapour resistance factor is mostly indicated as $\mu=5$ for soft fibreboards and $\mu=1-2$ for mineral fibrous insulating materials. Further, natural insulating materials beside soft fibreboards like cellulose, flax and hemp, sheep wool and cotton have similar values to mineral fibrous insulating materials (Albrecht 1997). The thermal conductivity of these insulating materials mostly ranges between 0.040 and $0.055 \mathrm{~W} / \mathrm{mK}$, but is lower for polyurethane and polystyrene cellular plastics that have, in contrast, a clearly higher water vapour resistance than the above mentioned materials (Albrecht 1997; Reyer et al. 2002). The theoretical bottom value of the thermal conductivity of these materials (if their density tends to zero) is given by the thermal conductivity of air with $0.026 \mathrm{~W} / \mathrm{mK}$ neglecting radiation and air flow (Kollmann 1951; Kollmann and Côté 1968; Scheiding 1998).

Therefore, for wood and wood-based materials, the thermal conductivity increases rather linearly with increasing density in the density range of 200 to $800 \mathrm{~kg} / \mathrm{m}^{3}$ but decreases with decreasing particle size of the material (Kollmann 1951; Kollmann and Malmquist 1956; Kollmann and Côté 1968; Sonderegger and Niemz 2009). However, for soft fibreboards and other insulating materials with very low densities, the reduction of the thermal conductivity with decreasing density diminishes, eventually stops and then changes below about $40 \mathrm{~kg} / \mathrm{m}^{3}$ and begins to increase due to cumulative gaseous flow and radiation exchange in the voids (Häupl 2008). This behaviour can also be found for wood-based loose-fill thermal insulation materials (Scheiding 1998; Schunk et al. 2009), hemp fibres (Grohe 2004) and textiles (Martin and Lamb 1987; Schardt et al. 1993).

Many sorption theories exist (Skaar 1988 gives a broad overview) and sorption behaviour of the main wood species and wood-based materials are also very well known (recent investigations e.g. Sonderegger and Niemz 2006; Popper and Niemz 2009), however the sorption of soft fibreboards has scarcely been investigated. According to Scheiding (1998) the sorption behaviour of wood fibres and therefore soft fibreboards is comparable to solid wood. In recent years, investigations have been carried out on diverse natural fibres, not only for use as insulating material but also for polymer composite material (Alix et al. 2009; Bessadok et al. 2009; Hill et al. 2009). Diverse factors such as the manufacturing method (Seifert 1972), the treatment of the fibres (Bessadok et al. 2009) and the additives (Kollmann and Schneider 1959; Scheiding 1998; Lesar et al. 2009) influence the sorption of natural fibres and fibreboards. The
Hailwood-Horrobin model is often used to characterise the sorption isotherms of wood and adequately describes the sorption of other natural fibres (Hill et al. 2009), and is used for modelling moisture transport in wood (e.g. Frandsen et al. 2007).

In this study the properties of thermal conductivity, water vapour diffusion and water sorption were investigated for different types of soft fibreboards relative to the temperature, moisture content (MC) and density of the material.

\section{Materials and methods}

\subsection{Thermal conductivity}

28 industrially fabricated types of soft fibreboard varying in thickness and density from four different companies were investigated. 16 types were manufactured with the wet process and 12 types with the dry process. Table 1 gives an overview of the investigated boards.

The specimens used to determine the thermal conductivity were sized $500 \mathrm{~mm} \times 500 \mathrm{~mm} \times$ sample thickness. Before testing, the boards were conditioned at standard climatic conditions of $20^{\circ} \mathrm{C}$ and $65 \%$ relative humidity (RH) and 5 boards were additionally conditioned at $20^{\circ} \mathrm{C}$ and $80 \%$ $\mathrm{RH}$ as well as at $35 \% \mathrm{RH}$ and at oven dry conditions for the purpose of determining the influence of moisture (Table 1). The measurements were carried out with the guarded hot plate apparatus $\lambda$-Meter EP500 (Lambda-Messtechnik $\mathrm{GmbH}$, Dresden) according to ISO 8302:1991 at 10, 20, and $30^{\circ} \mathrm{C}$. With a linear regression through the values at the three temperatures, the thermal conductivity at $10^{\circ} \mathrm{C}$ $\left(\lambda_{10 \cdot \operatorname{reg}(T)}\right)$ and the change of the thermal conductivity with increasing temperature per degree Celsius $\left(\Delta \lambda_{\left.(T) /{ }^{\circ} \mathrm{C}\right) \text { were }}\right.$ determined according to (1):

$\lambda_{(T)}=\lambda_{10 \cdot \operatorname{reg}(T)}+\Delta \lambda_{(T) /{ }^{\circ} \mathrm{C}} \cdot(T-10)$

where $T$ is the temperature $\left[{ }^{\circ} \mathrm{C}\right]$.

\subsection{Water vapour diffusion}

For measuring the water vapour resistance of the investigated soft fibreboards and the water vapour diffusion perpendicular to the plane, three cylindrical specimens of $140 \mathrm{~mm}$ diameter $x$ board thickness per climate and type were tested (Table 1). The tests to determine the water vapour resistance were carried out according to ISO $12572: 2001$ under 'dry cup' $\left(20^{\circ} \mathrm{C}-0 / 65 \% \mathrm{RH}\right)$ and 'wet cup' conditions $\left(20^{\circ} \mathrm{C}-100 / 65 \% \mathrm{RH}\right)$. Figure 1 shows the test assembly. The specimens were first conditioned at standard climatic conditions $\left(20^{\circ} \mathrm{C} / 65 \% \mathrm{RH}\right)$ and then put on top of a glass vessel filled up to approximately $20 \mathrm{~mm}$ under the brim with either a desiccant (silica gel) or totally 
Table 1 Overview of the investigated types of soft fibreboard and the number of tested specimens

Tab. 1 Überblick über die untersuchten Holzfaserdämmplatten und die Anzahl der Proben

\begin{tabular}{|c|c|c|c|c|c|c|c|c|}
\hline \multirow[t]{2}{*}{ Class } & \multirow[t]{2}{*}{ Company } & \multirow[t]{2}{*}{ Additives } & \multirow{2}{*}{$\begin{array}{l}\text { Manufacturing } \\
\text { method }\end{array}$} & \multirow{2}{*}{$\begin{array}{l}\text { Thickness } \\
{[\mathrm{mm}]}\end{array}$} & \multirow{2}{*}{$\begin{array}{l}\text { Density } \\
{\left[\mathrm{kg} / \mathrm{m}^{3}\right]}\end{array}$} & \multicolumn{3}{|c|}{ Number of tested specimens per type } \\
\hline & & & & & & Thermal conductivity ${ }^{4}$ & Diffusion & Sorption \\
\hline 1 (2 types) & 1 & $\begin{array}{l}\text { Binding fibres } \\
\text { (polyolefin); } \\
\text { ammonium } \\
\text { polyphosphate }\end{array}$ & Dry process & 30,60 & 55 & 3 & $2 \times 3$ & 3 \\
\hline 2 (2 types) & 1 & $\begin{array}{l}\text { Cellulose particles } \\
\text { from newsprint } \\
\text { (without wood fibres); } \\
\text { binding fibres } \\
\text { (polyolefin); sodium } \\
\text { borate; boric acid }\end{array}$ & Dry process & 30,60 & 75 & 3 & $2 \times 3$ & 3 \\
\hline 3 (3 types) & 2 & PUR-resin $(4 \%)$ & Dry process & 60 & $120,135,140$ & 3 & $2 \times 3$ & 3 \\
\hline 4 (2 types) & 2 & $\begin{array}{l}\text { PUR-resin }(4 \%) \\
\text { paraffin }(2 \%)\end{array}$ & Dry process & 60 & 165,240 & 3 & $2 \times 3$ & 3 \\
\hline $5(3 \text { types })^{1}$ & 3 & $\begin{array}{l}\text { Binding fibres } \\
\text { (copolyester); } \\
\text { ammonium phosphate }\end{array}$ & Dry process & $60,100,160$ & $140,105,50$ & 5 & - & 3 \\
\hline 6 ( 2 types) & 2 & $\begin{array}{l}\text { Saponified wood } \\
\text { resin; wax emulsion }\end{array}$ & Wet process & 18,36 & 260 & 5 & $2 \times 3$ & 3 \\
\hline $7(8 \text { types })^{2}$ & 2 & - & Wet process & $\begin{array}{l}20,60 \\
(50,80)\end{array}$ & $\begin{array}{l}150,180,185 \\
(220)\end{array}$ & 5 & $2 \times 3$ & 3 \\
\hline $8(2 \text { types })^{3}$ & 4 & $\begin{array}{l}\text { Starch }(5 \%) ; \text { paraffin } \\
(0.5 \%)\end{array}$ & Wet process & 20 & 185,215 & 5 & $2 \times 3$ & 3 \\
\hline $9(2 \text { types })^{1}$ & 4 & - & Wet process & 19,22 & 205,130 & 5 & $2 \times 3$ & 3 \\
\hline 10 (2 types) & 4 & Latex & Wet process & 22 & 225,245 & 5 & $2 \times 3$ & 3 \\
\hline
\end{tabular}

${ }^{1}$ Types attribution: Each thickness corresponds to only one density (same order) per sample type

${ }^{2}$ Types attribution: The thicknesses in brackets correspond to the density in brackets and the other thicknesses to the other densities

${ }^{3}$ One sample type (density $185 \mathrm{~kg} / \mathrm{m}^{3}$ ) without paraffin

${ }^{4}$ Tests at standard climatic conditions and for 5 sample types ( 1 sample type of class 1, class 2 and class 7 (only 3 specimens per type) and both sample types of class 9) additionally at three further climates

desalinated water. The specimens were laterally sealed with a tight-fitting circular rubber band. After attaining the equilibrium moisture content (EMC), the vessels with the specimens were weighed seven times with an interval of 1 to 3 days between each weighing depending on the thickness and the permeability of the respective specimen. The water vapour resistance factor was calculated according to Annex G of ISO 12572 taking into account the thickness of the air layer in the test cup between the base of the specimen and the desiccant or the desalinated water, respectively (cf. Sonderegger and Niemz 2009):

$\mu=\frac{\delta_{a}}{d} \cdot\left(\frac{A \cdot \Delta p_{v}}{G}-\frac{d_{a}}{\delta_{a}}\right)$

where $\mu$ is the water vapour resistance factor $[-], \delta_{a}$ the water vapour permeability of air with respect to the partial vapour pressure $[\mathrm{kg} /(\mathrm{m} \mathrm{sPa})], d$ the mean thickness of the specimen $[\mathrm{m}], A$ the area of the specimen $\left[\mathrm{m}^{2}\right], \Delta p_{v}$ the water vapour pressure difference across the specimen $[\mathrm{Pa}]$,
$G$ the water vapour flow rate through the specimen $[\mathrm{kg} / \mathrm{s}]$, and $d_{a}$ the thickness of the air layer in the test cup between the base of the specimen and the desiccant or the desalinated water $[\mathrm{m}]$.

In contrast to the water vapour resistance factor, which was determined on the basis of a water vapour pressure difference, the diffusion coefficient was determined on the basis of a water concentration difference within the specimen according to Siau (1995, p. 111) following Fick's first law:

$D=\frac{G}{A} \cdot \frac{d}{\Delta c}$

where $D$ is the diffusion coefficient $\left[\mathrm{m}^{2} / \mathrm{s}\right]$ and $\Delta c$ the water concentration difference $\left[\mathrm{kg} / \mathrm{m}^{3}\right]$.

Thereby, for determining the water concentration difference in the specimen, the gradient of the MC through the specimen was assumed to be linear. Thus, with the values of the EMC at standard climatic conditions $\left(20^{\circ} \mathrm{C} / 65 \% \mathrm{RH}\right.$ corresponding to the upper side of the specimen) and the 


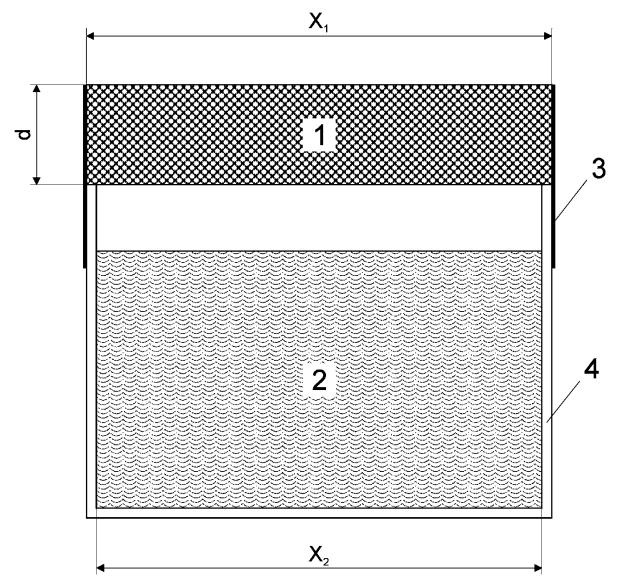

Fig. 1 Water vapour transmission properties: Test assembly for the 'dry cup' and 'wet cup' tests. 1 - test specimen with $X_{1}$ and $X_{2}$ as the upper and lower exposed area and with the thickness $d$; 2-desiccant/desalinated water; 3-rubber band; 4-glass vessel

Abb. 1 Wasserdampfdurchlässigkeit: Prüfanordnung unter ,dry cup" und ,wet cup" Bedingungen. 1-Probekörper mit $X_{1}$ und $X_{2}$ als oberer und unterer Prüffläche und mit der Dicke $d$; 2-Trockenmittel/entsalztes Wasser; 3-Gummiband; 4-Glasgefäß

mean moisture of the specimen during the diffusion experiment, the water concentration difference could be calculated as follows:

$\Delta c=2 \cdot\left|\mathrm{MC}_{20 / 65}-\mathrm{MC}_{\text {mean }}\right| \cdot \frac{V}{m_{\mathrm{dry}}}$

where $\mathrm{MC}_{20 / 65}$ is the moisture content at $20^{\circ} \mathrm{C} / 65 \% \mathrm{RH}[-]$, $\mathrm{MC}_{\text {mean }}$ the mean moisture content of the specimen during the experiment $[-], V$ the volume of the specimen $\left[\mathrm{m}^{3}\right]$, and $m_{\text {dry }}$ the oven-dry weight $[\mathrm{kg}]$.

\subsection{Sorption}

The sorption was tested on three specimens of $10 \mathrm{~cm} \times$ $15 \mathrm{~cm} \times$ board thickness per type measuring the EMC for the adsorption at $20^{\circ} \mathrm{C}$ and $35 \%, 50 \%, 65 \%, 80 \%$ and 93\% RH and for the desorption (only for the dry processed boards) at $20^{\circ} \mathrm{C}$ and $93 \%, 90 \%, 80 \%, 65 \%, 50 \%$ and $35 \%$ RH (Table 1). The specimens were dried at $60^{\circ} \mathrm{C}$ before the adsorption tests. The single hydrate Hailwood-Horrobin model was used for determining the sorption isotherms and is comparable to the Dent-model. Therefore, according to Skaar (1988), the parameters $A, B$ and $C$ were calculated for all board types from the experimental data according to (5). From this, the complete hydration or complete monolayer coverage of all available sorption sites (6) and the total sorption isotherm (7) as well as the hydrated and dissolved water of the Hailwood-Horrobin model (8) and (9) and the primary and secondary sorbed water of the Dent model (10) and (11) were determined:

$\frac{h}{m}=A+B \cdot h-C \cdot h^{2}$
$M_{0}=\frac{100}{\sqrt{\left(B^{2}+4 \cdot A \cdot C\right)}}$

$M=M_{h}+M_{d}=M_{1}+M_{2}$

$M_{h}=M_{0} \cdot \frac{K_{h} \cdot K_{d} \cdot h}{1+K_{h} \cdot K_{d} \cdot h}$

$M_{d}=M_{0} \cdot \frac{K_{d} \cdot h}{1-K_{d} \cdot h}$

$M_{1}=M_{0} \cdot \frac{b_{1} \cdot h}{1-b_{2} \cdot h+b_{1} \cdot h}$

$M_{2}=M_{0} \cdot \frac{b_{1} \cdot b_{2} \cdot h^{2}}{\left(1-b_{2} \cdot h\right) \cdot\left(1-b_{2} \cdot h+b_{1} \cdot h\right)}$

where

$K_{d}=b_{2}=\frac{-B+\sqrt{B^{2}+4 \cdot A \cdot C}}{2 \cdot A}$

$K_{h}=\frac{B}{A \cdot K_{d}}+1$

$b_{1}=\frac{B}{A}+2 \cdot b_{2}$

$h \quad$ Relative humidity [-]

$m \quad$ Moisture content [-]

$A, B, C$ Parameter [-]

$M_{0} \quad$ MC corresponding to the complete hydration (Hailwood-Horrobin model) or complete monolayer coverage of all available sorption sites (Dent model) [\%]

M Total MC [\%]

$M_{h} \quad$ MC of the hydrated water [\%]

$M_{d} \quad$ MC of the dissolved water [\%]

$M_{1} \quad$ MC of the primary sorbed water [\%]

$M_{2} \quad$ MC of the secondary sorbed water [\%]

$K_{d}, K_{h}$ Coefficients of the Hailwood-Horrobin model [-]

$b_{1}, b_{2} \quad$ Coefficients of the Dent model [-]

To ascertain the curve given by (5) in the lower humidity range, in addition to the values of the EMCs at the abovementioned relative humidities, the $\mathrm{MC}$ after drying at $60^{\circ} \mathrm{C}$ was also used as an auxiliary data point under the assumption that the humidity at $60^{\circ} \mathrm{C}$ corresponds to a $\mathrm{RH}$ of $4.7 \%$ (equal to $40 \% \mathrm{RH}$ at $20^{\circ} \mathrm{C}$ for a similar vapour pressure). Following isohydro curves on this humidity range (e.g. for Sitka spruce in Niemz 1993) the MC of a defined RH at $60^{\circ} \mathrm{C}$ corresponds to about two-thirds of this $\mathrm{RH}$ at $20^{\circ} \mathrm{C}$. Thus for this auxiliary data point a RH of $3.13 \%$ was used.

\section{Results and discussion}

\subsection{Thermal conductivity}

Figure 2 shows the thermal conductivity dependant on density. Overall, the thermal conductivity increases with increasing density. As one can see, the results of the wet and 


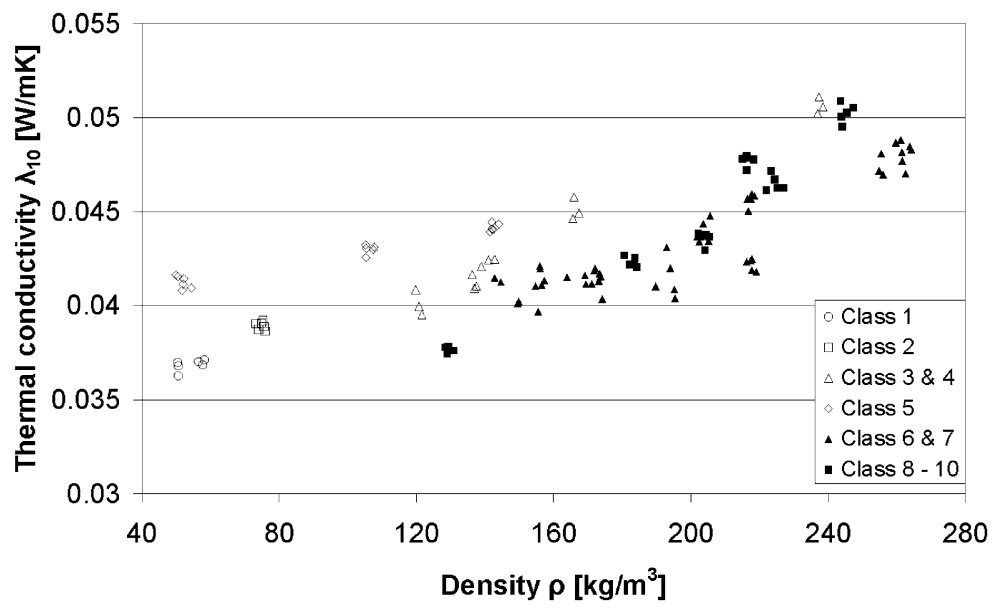

Fig. 2 Thermal conductivity depending on the density and grouped by classes. Empty symbols represent dry processed and solid symbols represent wet processed materials. $\lambda_{10}=$ Thermal conductivity at $10^{\circ} \mathrm{C} / 65 \% \mathrm{RH}$

Abb. 2 Wärmeleitfähigkeit in Abhängigkeit von der Dichte unterteilt nach Klassen. Leere Symbole bezeichnen nach dem Trockenverfahren und ausgefüllte Symbole nach dem Nassverfahren hergestellte Materialien. $\lambda_{10}=$ Wärmeleitfähigkeit bei $10^{\circ} \mathrm{C} / 65 \%$ relativer Luftfeuchte

the dry processed boards sit distinctly apart. Thereby, two points attract special attention: Firstly, the lowest density of the wet processed materials is located at about $130 \mathrm{~kg} / \mathrm{m}^{3}$ due to the process conditions, whereas a density of $50 \mathrm{~kg} / \mathrm{m}^{3}$ for the dry processed boards can be manufactured. Secondly, the thermal conductivity at the same density is lower for the wet processed than for the dry processed boards. This can be partially attributed to the glue fraction and the porosity distribution but is predominantly a result of the orientation of the fibres in the board. The thermal conductivity parallel to the grain is about 2.25 to 2.75 times higher than perpendicular to the grain (Kollmann and Côté 1968). This signifies that the orientation of the grain in the boards impacts the extent of the thermal conductivity. Due to the high water content of the wet process and the lower thickness of a single board, the fibres are highly oriented in the plane of the board, clearly more so than by the dry process. As an example, the higher insulating effect of multi-layered solid wood panels with soft fibreboards as middle layers totally disappears if the middle layers were cut into strips and turned $90^{\circ}$ and glued again so that the originally in plane orientation was now perpendicular to the plane (Schulz and Tobisch 2006).

With $\lambda<0.040 \mathrm{~W} / \mathrm{mK}$ below a density of $140 \mathrm{~kg} / \mathrm{m}^{3}$, Müller (1998) determined similar values for wet processed starch bonded fibreboards on wet processed materials, as was measured in this study.

A phenomenon already observed for insulating material by Häupl (2008), the decrease of the thermal conductivity in Fig. 2, diminishes with decreasing density for very low densities.

The mean increase of the thermal conductivity with increasing temperature $\left(\Delta \lambda_{(T) /{ }^{\circ} \mathrm{C}}\right.$ according to (1)) in the range of $10^{\circ} \mathrm{C}$ to $30^{\circ} \mathrm{C}$ amounts (over all types of soft fibreboards) to $0.19 \pm 0.05 \times 10^{-3} \mathrm{~W} / \mathrm{mK}$ or $0.45 \pm 0.13 \%$ per Kelvin. The absolute increase is lower but the percentage increase is similar or higher compared to values determined on wood-based boards of medium or high density (OSB, MDF and others) in Sonderegger and Niemz (2009).

Table 2 shows the thermal conductivity of five board types depending on $\mathrm{MC}$ and the corresponding regression parameters. For one of these boards (type 2 of class 9), the increase of the thermal conductivity with increasing MC at the three measured temperatures $\left(10^{\circ} \mathrm{C}, 20^{\circ} \mathrm{C}, 30^{\circ} \mathrm{C}\right)$ is shown in Fig. 3.

Furthermore, the increase of the thermal conductivity with increasing MC depends on density if the MC is drymass-referred as it is usual for wood and wood-based materials (cf. Table 2). In contrast, according to Cammerer (1987) the increase of the thermal conductivity depending on volumetric MC gives similar values for similar materials independent of the density. Figure 4 illustrates this dependency for the investigated boards. The increase in thermal conductivity is similar for all boards. The mean increase per percent volumetric MC amounts to $0.17 \times 10^{-2} \mathrm{~W} / \mathrm{mK}$ and is about $30 \%$ lower than given by Cammerer for wood and cork. Another approach towards analyzing the moisture dependent increase of the thermal conductivity is by determining the percentage increase of the thermal conductivity per MC (dry mass referred) specified in Künzel (1986). This alternative approach is also independent of the density (for materials with higher densities and a high correlation between thermal conductivity and density) and has the advantage that the hygroscopic equilibrium of the moisture is taken into account. However, for the investigated soft fibreboards, the influence of the density with this calculation method is still high. Thus, the percentage increase of 
Table 2 Thermal conductivity $(\lambda)$ dependant on the moisture content $(\omega)$ determined on the regression $\lambda=A+B \cdot \omega$, where $A=\lambda_{10}$.dry $(\lambda$ at dry condition and $10^{\circ} \mathrm{C}$ ) and $B=\Delta \lambda_{\omega}$ (change of $\lambda$ per percent $\mathrm{MC}$ in $\mathrm{W} /(\mathrm{m} \mathrm{K})$ )

Tab. 2 Wärmeleitfähigkeit $(\lambda)$ in Abhängigkeit vom Feuchtegehalt $(\omega)$, ermittelt anhand der Regressionsgleichung $\lambda=A+B \cdot \omega$, wobei $A=\lambda_{10 \text {.dry }}\left(\lambda\right.$ von darrtrockenen Platten bei $10^{\circ} \mathrm{C}$ ) und $B=\Delta \lambda_{\omega}$ (Änderung von $\lambda$ pro Prozent Feuchteänderung in W/(m K))

\begin{tabular}{|c|c|c|c|c|c|c|c|c|}
\hline \multirow[t]{2}{*}{ Material } & \multirow{2}{*}{$\begin{array}{l}\text { Thickness }^{1} \\
{[\mathrm{~mm}]}\end{array}$} & \multirow{2}{*}{$\begin{array}{l}\text { Density }{ }^{1} \\
{\left[\mathrm{~kg} / \mathrm{m}^{3}\right]}\end{array}$} & \multicolumn{3}{|c|}{$\omega[\%]$ at climates } & \multicolumn{3}{|c|}{ Regressionparameter } \\
\hline & & & $20 / 35$ & $20 / 65$ & $20 / 85$ & $\overline{A\left(=\lambda_{10 . d r y}\right)}$ & $B\left(=\Delta \lambda_{\omega}\right)$ & $\overline{R^{2}}$ \\
\hline Class 1 , type 1 & 29 & 55 & 7.6 & 10.1 & 14.6 & 0.0360 & $0.90 \times 10^{-4}$ & 0.96 \\
\hline Class 2, type 1 & 31 & 75 & 8.1 & 11.1 & 15.2 & 0.0371 & $1.38 \times 10^{-4}$ & 0.95 \\
\hline Class 7 , type 1 & 22 & 150 & 8.1 & 10.3 & 15.1 & 0.0384 & $2.06 \times 10^{-4}$ & 0.87 \\
\hline Class 9, type 1 & 21 & 205 & 8.2 & 11.3 & 15.2 & 0.0411 & $3.25 \times 10^{-4}$ & 0.89 \\
\hline Class 9 , type 2 & 23 & 130 & 7.8 & 10.3 & 14.2 & 0.0360 & $2.04 \times 10^{-4}$ & 0.91 \\
\hline
\end{tabular}

${ }^{1}$ At climatic condition of $20^{\circ} \mathrm{C}$ and $65 \% \mathrm{RH}$

Fig. 3 Thermal conductivity depending on $\mathrm{MC}$ of type 2 of class 9 (density $130 \mathrm{~kg} / \mathrm{m}^{3}$ )

Abb. 3 Wärmeleitfähigkeit in Abhängigkeit von der Feuchte (Variante 2 der Klasse 9: Dichte $130 \mathrm{~kg} / \mathrm{m}^{3}$ )

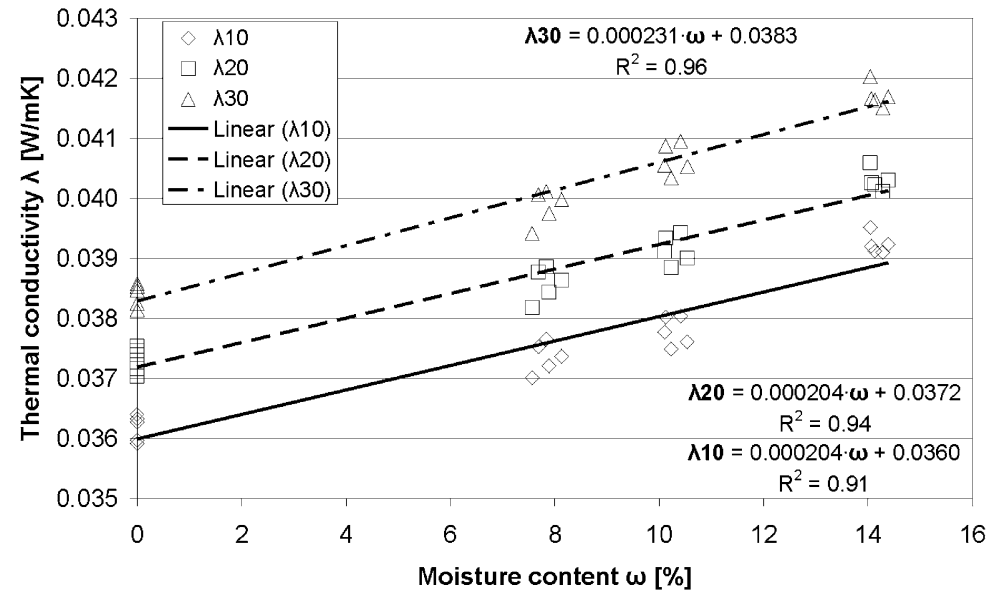

Fig. 4 Increase of thermal conductivity depending on volumetric moisture

Abb. 4 Zunahme der Wärmeleitfähigkeit in Abhängigkeit vom volumenbezogenen Feuchtegehalt

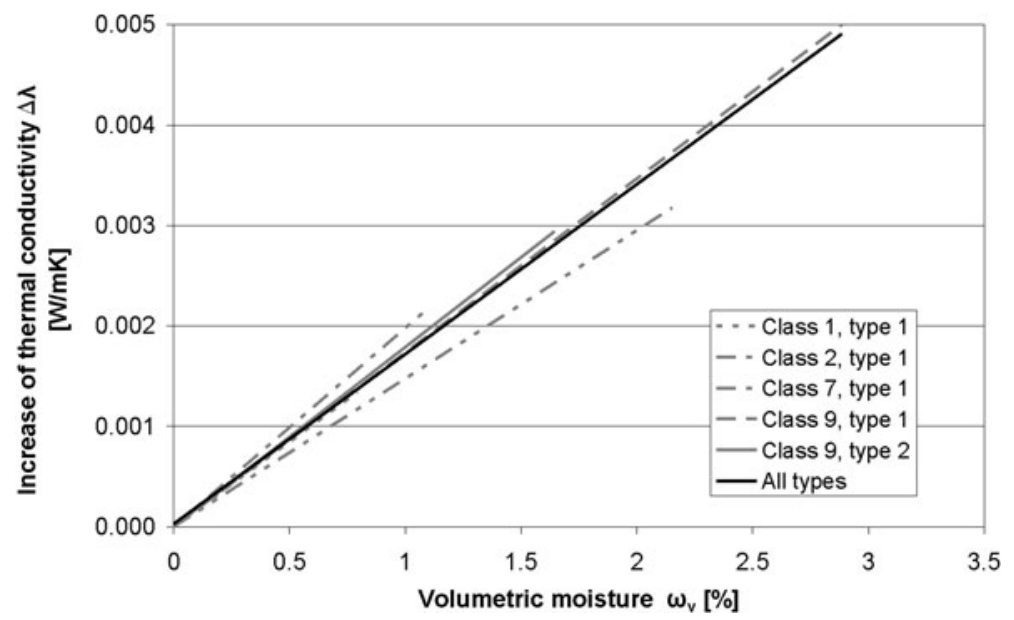

the thermal conductivity per $1 \%$ change of MC lies between $0.25 \%$ and $0.79 \%$ and increases with increasing density. The mean value corresponds to tests on cellulose flakes insulation by Kehrer et al. (2001) and sodium and potassium silicate bonded soft fibreboards in the lower humidity range by Scheiding (1998).

\subsection{Water vapour diffusion}

Figure 5 shows the water vapour resistance factor $\mu$ of the 'wet cup' and the 'dry cup' tests depending on density. The mean values are listed in Table 3. All types of soft fibreboard have a low resistance factor but a clear difference between 


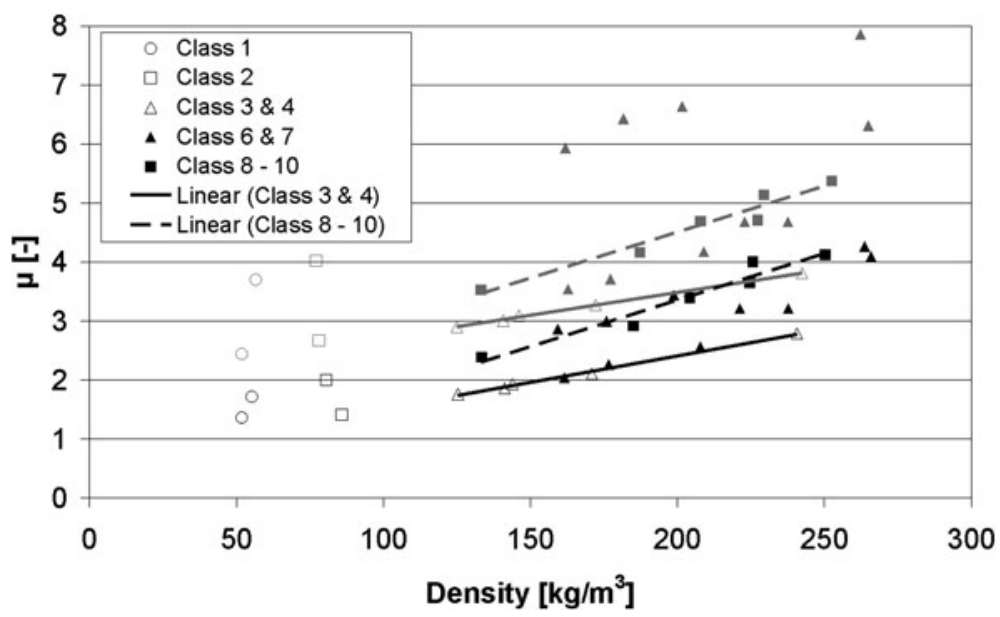

Fig. 5 Water vapour resistance factor $(\mu)$ of the 'wet cup' tests (black symbols) and the 'dry cup' tests (grey symbols) depending on the density (mean values). Empty symbols represent dry processed and solid symbols represent wet processed materials

Abb. 5 Wasserdampfdiffusionswiderstandszahlen $(\mu)$ im Feuchtbereich (schwarze Symbole) und im Trockenbereich (graue Symbole) in Abhängigkeit von der Dichte (Mittelwerte). Leere Symbole bezeichnen nach dem Trockenverfahren und ausgefüllte Symbole nach dem Nassverfahren hergestellte Materialien

Table 3 Mean water vapour resistance factors $(\mu)$ of the dry and wet processed soft fibreboards

Tab. 3 Gemittelte Wasserdampfdiffusionswiderstandszahlen $(\mu)$ der im Trocken- und Nassverfahren hergestellten Holzfaserdämmplatten

\begin{tabular}{llll}
\hline & $\mu_{\text {wet-cup }}$ & $\mu_{\text {dry-cup }}$ & $\mu_{\text {mean }}$ \\
\hline Dry processed & $1.89 \pm 0.42$ & $3.22 \pm 0.53$ & $2.55 \pm 0.44$ \\
Wet processed & $3.22 \pm 0.70$ & $5.10 \pm 1.24$ & $4.16 \pm 0.90$ \\
All types & $2.74 \pm 0.89$ & $4.42 \pm 1.38$ & $3.58 \pm 1.09$ \\
\hline
\end{tabular}

dry and wet processed boards can be observed. Further, the water vapour resistance factor is, up to factor 2 , higher in the dry climate than in the wet climate and increases in both climates with increasing density but only with a low correlation due to other different factors influencing the water vapour resistance such as composition, thickness and manufacturing (Fig. 5). Therefore, a linear regression curve is plotted for only two groups of boards with similar properties and thicknesses within the group.

Figure 6 shows the diffusion coefficients calculated according to (3) depending on density. In both humidity ranges, the dry processed boards show higher diffusion coefficients than the wet processed boards. This may be due to the reduced percentage of in plane orientation fibres of the dry processed boards.

The diffusion coefficient in the dry climate is 1.5 to 3.1 times higher than in the wet climate, although the water vapour resistance factor has similar tendencies. This is due to the fact that the MC at high $\mathrm{RH}$ increases exponentially and therefore, at a low $\mathrm{RH}$, the water concentration difference at a given RH interval is much smaller than at a high RH. On the other hand the hygroscopic behaviour of the boards induces a swelling of the fibres and thus the voids decrease with increasing MC. Since water transport in the hygroscopic range generally takes place in the gaseous phase in boards with low density, a decrease of the diffusion coefficient with increasing MC is estimated.

\subsection{Sorption}

Table 4 gives an overview of the parameters describing the sorption isotherms according to the Hailwood-Horrobin and Dent model. On account of the boards' similar values, classes 3 and 4, 6 and 7 and 8 to 10 were each summarised as a single group.

Figure 7 shows the mean adsorption isotherm of classes 3 plus 4 and 8 to 10 and the mean adsorption and desorption isotherms of classes 6 and 7 according to the single hydrate Hailwood-Horrobin and the Dent model. Thereby, the primary water of the Dent model $\left(M_{1}\right)$ is slightly higher than the hydrated water of the Hailwood-Horrobin model $\left(M_{h}\right)$, and the secondary water of the Dent model $\left(M_{2}\right)$ is slightly lower than the dissolved water of the Hailwood-Horrobin model $\left(M_{d}\right)$. In contrast, the complete hydration (HailwoodHorrobin) or complete monolayer coverage (Dent) of all available sorption sites $\left(M_{0}\right)$ and the total sorption isotherm $(M)$ are equal in both models (cf. Skaar 1988).

The values of $M_{0}$ fall in the range $4.08 \%$ to $5.80 \%$ for adsorption and $5.03 \%$ to $8.80 \%$ for desorption (Table 4 and Fig. 7). Thereby, boards with binding fibres (e.g. polyolefin) have lower values than boards with only wood fibres, which have similar values to those calculated by Spalt in Skaar (1988) for spruce wood with $6.47 \%$ for adsorption and $8.11 \%$ for desorption. 


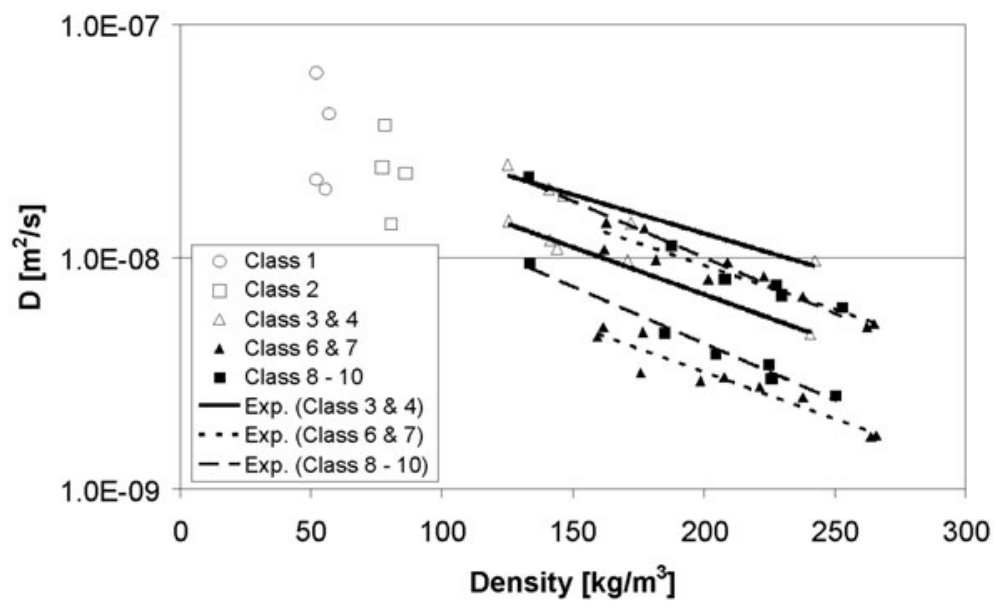

Fig. 6 Diffusion coefficients $(D)$ of the 'wet cup' tests (black symbols) and the 'dry cup' tests (grey symbols) depending on the density (mean values). Empty symbols represent dry processed and solid symbols represent wet processed materials

Abb. 6 Diffusionskoeffizienten $(D)$ im Feuchtbereich (schwarze Symbole) und im Trockenbereich (graue Symbole) in Abhängigkeit von der Dichte (Mittelwerte). Leere Symbole bezeichnen nach dem Trockenverfahren und ausgefüllte Symbole nach dem Nassverfahren hergestellte Materialien

Table 4 Parameters $(A, B, C)$ for the calculation of the sorption isotherms according to (5) and the fractions of the different moistures (as MC in percent) at $100 \% \mathrm{RH}$ according to the Hailwood-Horrobin and the Dent theory. $M_{0}=$ Complete hydration (Hailwood-Horrobin) or complete monolayer coverage (Dent) of all available sorption sites; $M=$ Total sorption; $M_{1}$ and $M_{2}=$ Primary and secondary water (Dent); $M_{h}$ and $M_{d}=$ Hydrated and dissolved water (Hailwood-Horrobin)

Tab. 4 Parameter $(A, B, C)$ zur Berechnung der Sorptionsisotherme gemäß Gleichung (5) und die Anteile der verschiedenen Feuchten (in Prozent Holzfeuchte) bei $100 \%$ relativer Luftfeuchte nach den Modellen von Hailwood-Horrobin und Dent. $M_{0}=$ Vollständige Hydratisierung (Hailwood-Horrobin) bzw. einschichtige Bedeckung (Dent) aller verfügbaren Sorptionsstellen; $M=$ Gesamte Sorption; $M_{1}$ and $M_{2}=$ Primäres und sekundäres Wasser (Dent); $M_{h}$ and $M_{d}=$ Hydratisiertes und gelöstes Wasser (Hailwood-Horrobin)

\begin{tabular}{|c|c|c|c|c|c|c|c|c|c|}
\hline Type & $A$ & $B$ & $C$ & $M_{0}$ & $M_{h}$ & $M_{d}$ & $M_{1}$ & $M_{2}$ & $M$ \\
\hline \multicolumn{10}{|l|}{ Adsorption } \\
\hline Class 1 , type $1(30 \mathrm{~mm})$ & 0.485 & 19.84 & 17.51 & 4.84 & 4.72 & 30.8 & 4.82 & 30.7 & 35.5 \\
\hline Class 1 , type $2(60 \mathrm{~mm})$ & 0.214 & 21.22 & 19.60 & 4.63 & 4.58 & 50.2 & 4.62 & 50.1 & 54.7 \\
\hline Class 2, type $1(30 \mathrm{~mm})$ & 0.388 & 19.34 & 16.87 & 5.00 & 4.90 & 29.9 & 4.98 & 29.9 & 34.8 \\
\hline Class 2 , type $2(60 \mathrm{~mm})$ & 0.439 & 23.75 & 20.78 & 4.08 & 4.01 & 25.4 & 4.07 & 25.3 & 29.4 \\
\hline Classes $3+4$ (mean) & 1.484 & 15.01 & 12.09 & 5.80 & 5.31 & 17.4 & 5.68 & 17.0 & 22.7 \\
\hline Class 5 , types $1+2$ (mean) & 0.316 & 23.58 & 20.93 & 4.14 & 4.09 & 29.7 & 4.14 & 29.6 & 33.8 \\
\hline Class 5, type $3(160 \mathrm{~mm})$ & 0.105 & 19.67 & 17.35 & 5.04 & 5.01 & 36.3 & 5.03 & 36.2 & 41.3 \\
\hline Classes $6+7$ (mean) & 1.232 & 16.29 & 13.67 & 5.48 & 5.11 & 20.8 & 5.41 & 20.5 & 26.0 \\
\hline Classes $8-10$ (mean) & 1.400 & 15.37 & 12.50 & 5.71 & 5.27 & 18.2 & 5.61 & 17.8 & 23.4 \\
\hline \multicolumn{10}{|l|}{ Desorption } \\
\hline Class 1 , type $1(30 \mathrm{~mm})$ & 0.751 & 13.70 & 11.34 & 6.71 & 6.38 & 25.8 & 6.65 & 25.5 & 32.2 \\
\hline Class 1 , type $2(60 \mathrm{~mm})$ & 0.491 & 15.29 & 13.78 & 6.19 & 6.00 & 44.0 & 6.17 & 43.8 & 50.0 \\
\hline Class 2, type $1(30 \mathrm{~mm})$ & 0.496 & 15.17 & 12.38 & 6.26 & 6.07 & 24.3 & 6.22 & 24.1 & 30.3 \\
\hline Class 2 , type $2(60 \mathrm{~mm})$ & 0.497 & 19.10 & 15.51 & 5.03 & 4.90 & 19.6 & 5.00 & 19.5 & 24.5 \\
\hline Classes $3+4$ (mean) & 1.689 & 9.28 & 6.37 & 8.80 & 7.56 & 14.2 & 8.32 & 13.4 & 21.7 \\
\hline Class 5 , types $1+2$ (mean) & 0.635 & 16.19 & 13.62 & 5.81 & 5.59 & 25.6 & 5.77 & 25.5 & 31.2 \\
\hline Class 5, type $3(160 \mathrm{~mm})$ & 0.384 & 14.43 & 12.34 & 6.63 & 6.47 & 33.9 & 6.61 & 33.7 & 40.3 \\
\hline
\end{tabular}

Figure 8 shows the total adsorption and desorption curves of classes 1,2 and 5 at each type. Thereby, the values at $100 \%$ RH were lower for desorption than for adsorption due to the fact that the measurements begin or end at $93 \%$ and not at $100 \%$ RH. Therefore, the true values of the desorption curves are higher in the upper hygroscopic range than the calculated ones. Although boards with binding fibres showed a lower $M_{0}$ than the other types with only 


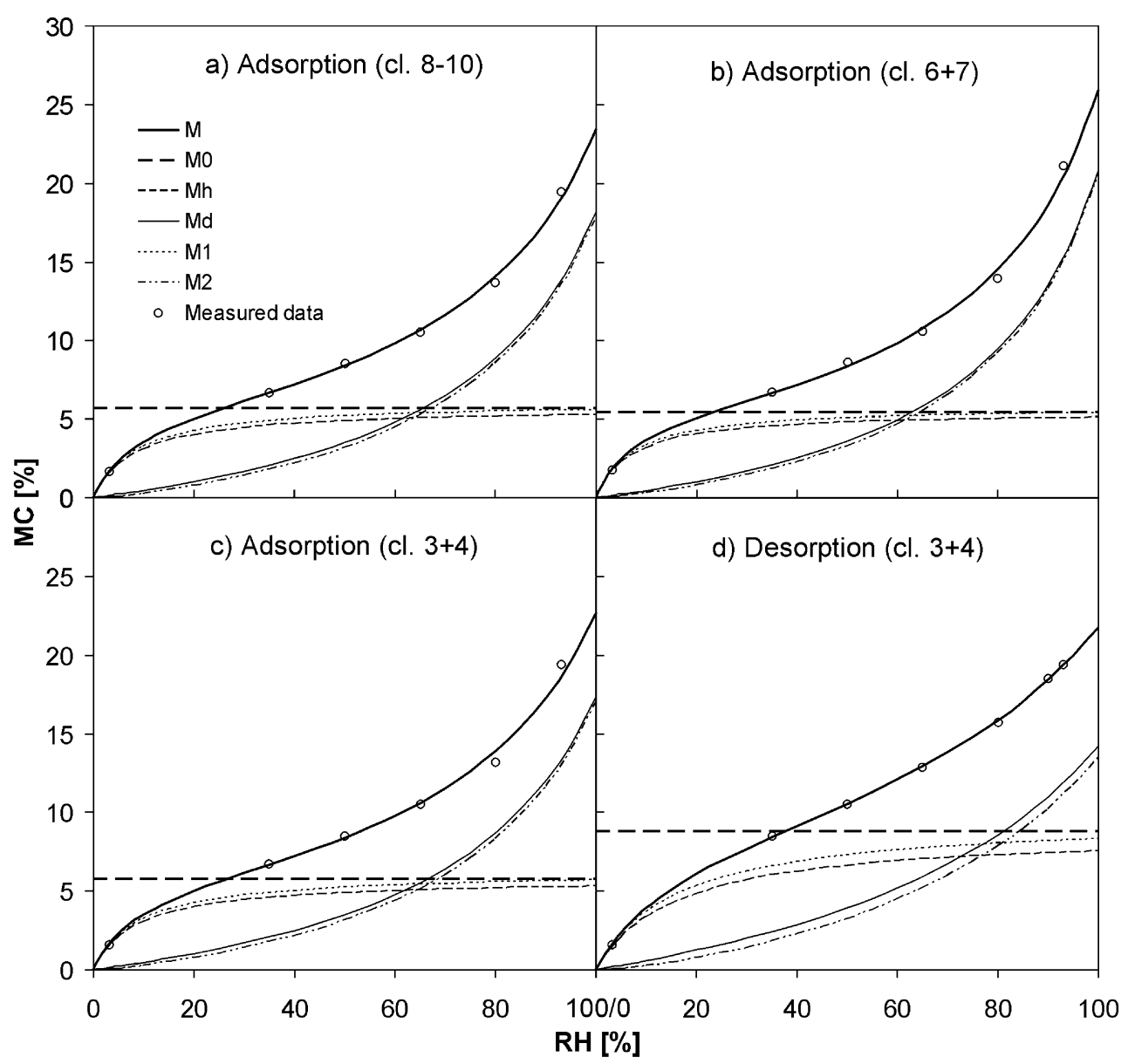

Fig. 7 Mean sorption isotherm of classes 8 to 10 (a), classes 6 plus 7 (b) and classes 3 plus 4 ((c) adsorption, (d) desorption) according to the Hailwood-Horrobin and the Dent model. $M=$ Isotherm of the total sorption; $M_{0}=$ Complete hydration (Hailwood-Horrobin) and complete monolayer coverage (Dent) of all available sorption sites; $M_{h}, M_{d}=$ Hydrated and dissolved water of the single hydrate Hailwood-Horrobin model; $M_{1}, M_{2}=$ Primary and secondary water of the Dent model

Abb. 7 Gemittelte Sorptionsisotherme der Klassen 8-10 (a), 6+ 7 (b) und 3+ 4 ((c) Adsorption, (d) Desorption) gemäß dem Hailwood-Horrobin- und dem Dent-Modell. $M=$ Isotherme der gesamten Sorption; $M_{0}=$ Vollständige Hydratisierung (Hailwood-Horrobin) bzw. einschichtige Bedeckung (Dent) aller verfügbaren Sorptionsstellen; $M_{h}, M_{d}=$ Hydratisiertes und gelöstes Wasser des einfach hydratisierten Hailwood-Horrobin-Modells; $M_{1}, M_{2}=$ Primäres und sekundäres Wasser des Dent-Modells

wood fibres (and therefore the sorption isotherm is lower in the predominant hygroscopic range as well), the sorption isotherm strongly increases above about $80 \% \mathrm{RH}$ and exceeds the sorption isotherms of the other boards (cf. also the $M$-values of Table 4 at $100 \% \mathrm{RH})$. This effect is probably due to the addition of additives (ammonium polyphosphate, borate and boric acid) that changed the saturation of water vapour in the air, and not due to the addition of binding fibres (cf. Kollmann and Schneider 1959; Seifert 1972; Lesar et al. 2009).

\section{Conclusion}

Both, thermal conductivity and water vapour diffusion of the investigated soft fibreboards depend on density but there are other properties such as temperature, $\mathrm{MC}$ and manufacturing method that also have a large impact. The thermal conductivity increases with increasing temperature at about $0.45 \%$ per Kelvin and with increasing moisture at about $0.17 \times 10^{-2} \mathrm{~W} / \mathrm{mK}$ per percent volumetric MC. In contrast, the influence of the dry mass referred MC depends strongly on density but is clearly lower than $1 \%$ per change of $1 \% \mathrm{MC}$. Furthermore, the thermal conductivity depends on the manufacturing method of the boards and therefore the different orientation of the fibres in the boards.

The water vapour resistance factor is, up to factor 2, higher in the dry climate than in the wet climate. This tendency could be detected in the same order for the diffusion coefficient what primarily can be derived from the sigmoid sorption isotherm. Further, the diffusion coefficient is influ- 
Fig. 8 Adsorption (a) and desorption isotherms (b) of the complete water according to the Hailwood-Horrobin and Dent model of the classes 1,2 and 5 separated per types

Abb. 8 Adsorptions- (a) und Desorptionsisothermen (b) des gesamten Wassers nach dem Hailwood-Horrobin- und Dent-Modell der Klassen 1, 2 und 5 aufgeteilt nach Typen

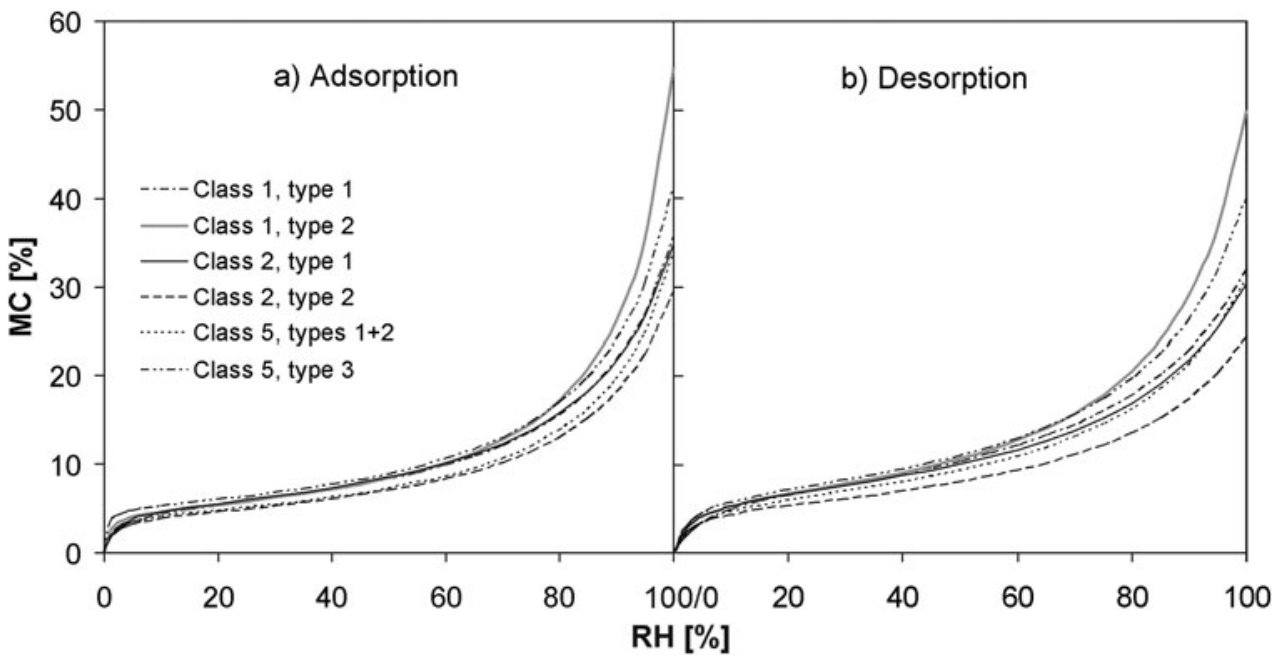

enced by the manufacturing method resulting in lower values for wet processed boards. For soft fibreboards with binding fibres and additives of ammonium phosphate or sodium borate and boric acid, the sorption isotherm above $80 \% \mathrm{RH}$ clearly differs from untreated boards due to a greater increase in MC.

\section{References}

Albrecht W (1997) Anwendungsgebiete, Eigenschaften und Klassifizierung von ,alternativen“ Wärmedämmstoffen. Bauphysik 19(4):121-125

Alix S, Philippe E, Bessadok A, Lebrun L, Morvan C, Marais S (2009) Effect of chemical treatments on water sorption and mechanical properties of flax fibres. Bioresour Technol 100:4742-4749

Bessadok A, Langevin D, Gouanvé F, Chappey C, Roudesli S, Marais S (2009) Study of water sorption on modified Agave fibres. Carbohydr Polym 76:74-85

Cammerer WF (1987) Der Feuchtigkeitseinfluss auf die Wärmeleitfähigkeit von Bau- und Wärmedämmstoffen. Bauphysik 9(6):259-266

Frandsen HL, Damkilde L, Svensson S (2007) A revised multi-Fickian moisture transport model to describe non-Fickian effects in wood. Holzforschung 61(5):563-572

Grohe B (2004) Heat conductivities of insulation mats based on water glass bonded non-textile hemp or flax fibres. Holz Roh- Werkst 62(5):352-357

Häupl P (2008) Bauphysik. Ernst \& Sohn, Berlin, p 66

Hill CAS, Norton A, Newman G (2009) The water vapor sorption behavior of natural fibers. J Appl Polym Sci 112:1524-1537

ISO 8302 (1991) Thermal insulation-determination of steady-state thermal resistance and related properties - guarded hot plate apparatus. Geneva

ISO 12572 (2001) Hygrothermal performance of building materials and products-determination of water vapour transmission properties. Geneva

Kehrer M, Künzel HM, Sedlbauer K (2001) Dämmstoffe aus nachwachsenden Rohstoffen-ist der Feuchtezuschlag für die Wärmeleitfähigkeit gerechtfertigt? IBP-Mitteilung 390, Stuttgart, p 2
Kollmann F (1951) Technologie des Holzes und der Holzwerkstoffe, 2nd edn. Anatomie und Pathologie, Chemie, Physik, Elastizität und Festigkeit, vol 1. Springer, Berlin

Kollmann F, Côté WA Jr (1968) Principles of wood science and technology. Solid wood, vol I. Springer, Berlin

Kollmann F, Malmquist L (1956) Über die Wärmeleitzahl von Holz und Holzwerkstoffen. Holz Roh- Werkst 14(6):201-204

Kollmann F, Schneider A (1959) Sorptionsmessungen an mit Salzen imprägnierten Hölzern. Holz Roh- Werkst 17(5):212-218

Künzel H (1986) Bestimmt der volumen- oder der massebezogene Feuchtegehalt die Wärmeleitfähigkeit von Baustoffen? Bauphysik 8(2):33-39

Lesar B, Gorisek Z, Humar M (2009) Sorption properties of wood impregnated with boron compounds, sodium chloride and glucose. Dry Technol 27(1):94-102

Martin JR, Lamb GER (1987) Measurement of thermal conductivity of nonwovens using a dynamic method. Text Res J 57:721-727

Müller M (1998) Möglichkeiten der Herstellung stärkegebundener lignocelluloser Formkörper als Variante dämmender, biologisch abbaubarer Werkstoffe. Dissertation, Technische Universität Dresden

Niemz P (1993) Physik des Holzes und der Holzwerkstoffe. DRWVerlag, Leinfelden-Echterdingen

Popper R, Niemz P (2009) Wasserdampfsorptionsverhalten ausgewählter heimischer und überseeischer Holzarten. Bauphysik 31(2):117-121

Reyer E, Schild K, Völkner S (2002) Kompendium der Dämmstoffe, 3rd edn. Fraunhofer IRB Verlag, Stuttgart

Schardt G, Mägel M, Gulich B (1993) Untersuchungen zum Wärmeisolationsverhalten von Nadelvliesstoffen. Tech Text 36(2):114-119

Scheiding W (1998) Entwicklung, Herstellung und Untersuchung wesentlicher Eigenschaften wasserglasgebundener Holzfaserdämmplatten aus Fichtenholz. Dissertation, Technische Universität Dresden

Schulz T, Tobisch S (2006) Untersuchungen zur Herstellung mehrlagiger Massivholzplatten unter Einsatz von Holzfaserdämmplatten als Mittellagen. Teil 2: Weiterführende Untersuchungen und Industrieversuche. Holztechnologie 47(3):5-12

Schunk C, Treml S, Tröger F (2009) Lose Dämmstoffe aus Holz Wärmeleitfähigkeit von speziell hergestellten Frässspänen ausgewählter Holzarten. Eur J Wood Prod 67(4):487-488 
Seifert J (1972) Zur Sorption und Quellung von Holz und Holzwerkstoffen. Erste Mitteilung: Einflüsse auf das Sorptionsverhalten der Holzwerkstoffe. Holz Roh- Werkst 30(3):99-111

Siau JF (1995) Wood: influence of moisture on physical properties. Department of Wood Science and Forest Products, Virginia Polytechnic Institute and State University, Keene, NY

Skaar C (1988) Wood-water relations. Springer, Berlin
Sonderegger W, Niemz P (2006) Untersuchungen zur Quellung und Wärmedehnung von Faser-, Span- und Sperrholzplatten. Holz Roh- Werkst 64(1):11-20

Sonderegger W, Niemz P (2009) Thermal conductivity and water vapour transmission properties of wood-based materials. Eur $\mathbf{J}$ Wood Prod 67(3):313-321 